\title{
First report of three scolytid species (Coleoptera: Curculionidae, Scolytinae) in Romania
}

\author{
N. Olenici, M. Knížek, V. Olenici, M.-L. Duduman, I.-A. Biriș
}

\begin{abstract}
Olenici N., Knížek M., Olenici V., Duduman M.-L., Biriș I.-A., 2014. First report of three scolytid species (Coleoptera: Curculionidae, Scolytinae) in Romania. Ann. For. Res. 57(1): 87-95, 2014.
\end{abstract}

Abstract. Scolytids constitute an insect group of forest ecosystems that is very important both ecologically and economically, and which has been well studied in most European countries. However, new species are found quite often, especially in regions searched less intensively to date. In this paper three species of scolytid fauna not previously known in Romania are reported for the first time: Trypodendron laeve, Xylosandrus germanus and Hylastes linearis. Individuals of all three species were collected in the north-eastern part of Romania. T. laeve was found only in natural coniferous forests, at altitudes above $1230 \mathrm{~m}$ and in association with T. lineatum, but in much lower abundance. The Asian species X. germanus was found in an old beech forest situated at a much higher altitude (760-900 m) than observed in western and central Europe. The third species, $H$. linearis, was captured as a single specimen in a plateau region $(375 \mathrm{~m})$. Keywords Hylastes linearis, Trypodendron laeve, Xylosandrus germanus, new records, Romanian fauna, alien invasive species.

Authors. Nicolai Olenici (olenicifp@yahoo.com), Valentina Olenici - Forest Research and Management Institute, Calea Bucovinei 73 bis, 725100 Câmpulung Moldovenesc, Romania; Miloš Knížek - Forestry and Game Management Research Institute, Jíloviště - Strnady, CZ-156 04 Praha 5 - Zbraslav, Czech Republic; Mihai-Leonard Duduman - Applied Ecology Lab, Forestry Faculty, "Ştefan cel Mare" University of Suceava, Universității 13, 720229 Suceava, Romania; Iovu-Adrian Biriş - Forest Research and Management Institute, Bulevardul Eroilor 128, 077190 Voluntari, Romania.

Manuscript received May 18, 2014; revised July 02, 2014; accepted July 08, 2014; online first July 09, 2014.

\section{Introduction}

Scolytid bark and ambrosia beetles constitute an essential structural and functional component of the forests, occupying a distinct posi- tion in the saproxylic food web of these very complex ecosystems (Stokland 2012). They initiate the process of decomposition of bark and wood tissues by feeding on them directly, and also by facilitating penetration by other in- 
sects, fungi and bacteria (Kirisits 2004, Persson et al. 2011, Hulcr et al. 2012, Stokland \& Siitonen 2012, Six 2013). While a few species are important pests (Postner 1974), some are even regarded as keystone species in forest ecosystems (Müller et al. 2008).

Given their importance, the scolytids have been studied for long time and quite intensively. As a consequence, they are relatively well known, especially in North America and Europe (Wood 1982, Pfeffer 1995, Knížek \& Beaver 2007). However, even in countries with long traditions of entomological research, new species continue to be described and species that have been overlooked to date, or which have only recently arrived from abroad, are still found (Kirkendall et al. 2008, Faccoli et al. 2009, Kirkendall \& Faccoli 2010, Faccoli \& Sidoti 2013).

Romania has enjoyed a good entomological tradition since the middle of the $19^{\text {th }}$ century, when a list of 29 scolytid species found in Transylvania was first published (Bielz 1851), followed by a second list containing 43 species (Bielz 1887). Just 25 years later, a total of 58 species were known for the same historical province (Petri 1912), compared to only 20 species reported for the other territories making up Romania (Fleck 1905, Eggers 1911). With the contributions of Marcu (1926, 1934, 1941, 1957), the number of reported species increased to 66 in subsequent years.

Between 1955 and 1971, Negru (1955, 1960, 1965, 1967, 1968, 1971), Negru \& Pîrvescu (1955), Negru \& Ceianu (1957), Paşcovici (1962) and Tudor (1969) published data on 18 new species of bark beetle. A further seven species previously unknown in the Romanian fauna were found in Ştefan Negru's collection (Vasiliu et al., 1978) after his premature death in 1970. Only four new species have been reported in the Romanian faunistic journals in the intervening period, by Bucşa \& Curtean (1995) and Kocs (2010), with several more published abroad and mentioned by Pfeffer (1995) and Knížek (2011). Altogether there have been 104 species reported for Romania so far.

The objective of this paper is to present three scolytid species reported in Romania for the first time and some data concerning their abundance and distribution.

\section{Materials and methods}

Site locations. Details about the research areas are provided in Figure 1 and Table 1.

The "Giumalău Old-Growth Forest Reserve" is located on the northern side of the Giumalău Mountains and is part of the Rarău-Giumalău Natura 2000 site. It is a pure Norway spruce forest of 309.5 ha, comprising uneven aged stands. The collection of insects took place at 20 and 32 collecting sites in 2007-2008 and 2009, respectively, in forest compartments $120 \mathrm{~A}$ and $121 \mathrm{~A}$, at $1230-1500 \mathrm{~m}$ altitude, on south-west facing slopes.

The forest reserve in the Călimani Mountains, named the "Dwarf Mountain Pine with Pinus cembra Reserve," is a strict nature reserve (IUCN protected area first category), included within the Călimani National Park and Călimani-Gurghiu Natura 2000 site. It covers 384.2 ha and is a habitat of Community interest, designed to protect plant species such as Pinus cembra L., Pinus mugo Turra and Rhododendron kotschyi Simonk. Despite its name, the main plant association is represented by mixed stands of Norway spruce (Picea abies (L.) H. Karst.) and Swiss stone pine (Pinus cembra L.), growing on mountain sides with varying slopes, a general north-easterly aspect and obvious signs of glaciation. The traps were set up in forest compartment 69A, at 1525$1720 \mathrm{~m}$ altitude.

Voievodeasa Forest Reserve is situated at the eastern edge of the Obcina Mare Mountains, in the subzone of montane mixed forests (European beech [Fagus sylvatica L.], European silver fir [Abies alba Mill.] and Norway spruce). The landscape is gentle and the climate mild. At the level of the reserve (size: $102 \mathrm{ha}$ ), the 


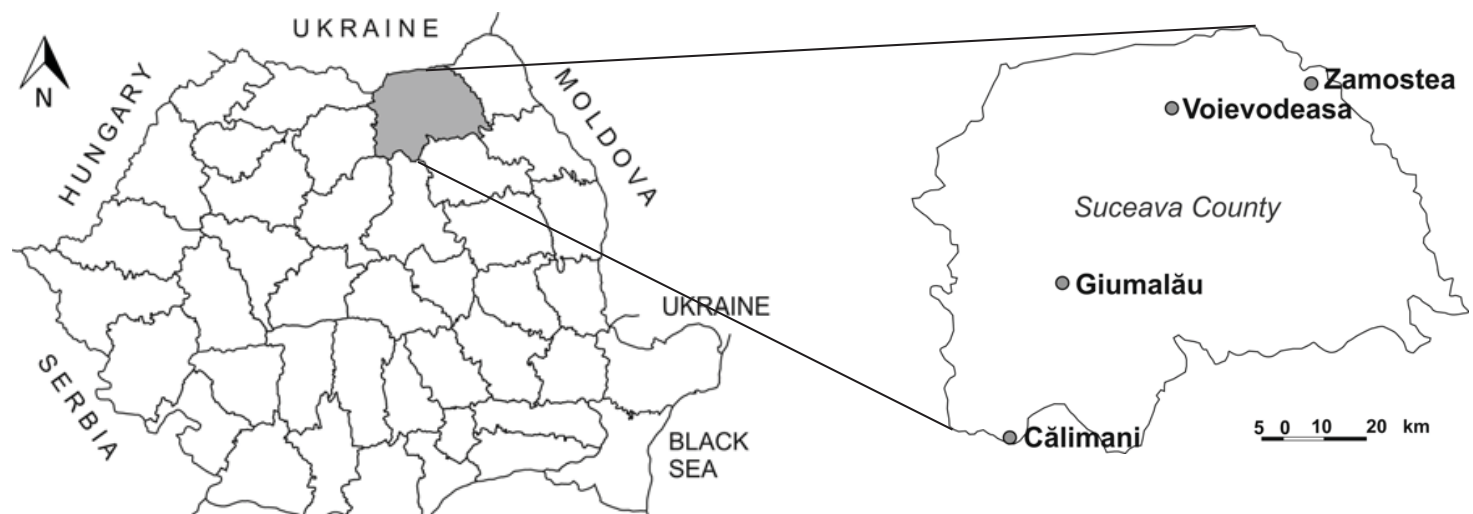

$200 \quad 50 \quad 100 \mathrm{~km} \quad$ BULGARIA

Figure 1 Locations of the study areas

Table 1 The main characteristics of the study areas

\begin{tabular}{|c|c|c|c|c|c|c|c|c|}
\hline Location & $\begin{array}{l}\text { Coordi- } \\
\text { nates }\end{array}$ & $\begin{array}{l}\text { Elevation } \\
(\mathrm{m})\end{array}$ & $\begin{array}{l}\text { Slope } \\
\left({ }^{\circ}\right)\end{array}$ & Aspect & $\begin{array}{l}\text { Mean } \\
\text { Annual } \\
\text { Temperature } \\
\left({ }^{\circ} \mathrm{C}\right) \\
\end{array}$ & $\begin{array}{l}\text { Mean } \\
\text { Annual } \\
\text { Precipitation } \\
(\mathrm{mm})\end{array}$ & $\begin{array}{l}\text { Forest } \\
\text { composition }\end{array}$ & $\begin{array}{l}\text { Forest } \\
\text { age } \\
\text { (years) }\end{array}$ \\
\hline Giumalău & $\begin{array}{l}47^{\circ} 26^{\prime} \mathrm{N} \\
25^{\circ} 29^{\prime} \mathrm{E}\end{array}$ & $1200-1650$ & $20-45$ & NW & $1.7-2.9$ & 924 & 100\% P.a. & uneven \\
\hline Călimani & $\begin{array}{l}47^{\circ} 06^{\prime} \mathrm{N} \\
25^{\circ} 15^{\prime} \mathrm{E}\end{array}$ & $1450-1780$ & $10-40$ & $\mathrm{NE}$ & $2.4-4.0$ & $970-1150$ & $\begin{array}{l}70 \% \text { P.a. } \\
\text { 30\% P.c. }\end{array}$ & uneven \\
\hline Voievodeasa & $\begin{array}{l}47^{\circ} 49^{\prime} \mathrm{N} \\
25^{\circ} 41^{\prime} \mathrm{E}\end{array}$ & $590-925$ & $12-18$ & $\mathrm{SE}$ & $6.5-7.8$ & $650-700$ & $\begin{array}{l}\text { 35\% F.s. } \\
\text { 35\% A.a. } \\
\text { 30\% P.a. }\end{array}$ & $35-130$ \\
\hline Zamostea & $\begin{array}{l}47^{\circ} 53^{\prime} \mathrm{N} \\
26^{\circ} 09^{\prime} \mathrm{E}\end{array}$ & 375 & - & - & 7.8 & 615 & 100\% P.a. & 45 \\
\hline
\end{tabular}

Note. P.a. - Picea abies, P.c. - Pinus cembra, F.s. - Fagus sylvatica, A.a. - Abies alba

tree species are almost equally represented. The traps were placed in the tree stand $5 \mathrm{~A}$, which is 44.2 ha in size and has a tree composition comprising $90 \%$ beech and $10 \%$ silver fir of ages 100-150 years. The stand is situated at 760-900 $\mathrm{m}$ altitude.

The Norway spruce stands in Zamostea forest are surrounded by broadleaf stands, mainly of beech and sessile oak (Quercus petraea (Matt.) Liebl.).

Two of the new species, Trypodendron laeve Eggers 1939, and Xylosandrus germanus (Blandford 1894), were found during studies of saproxylic beetles conducted in the forest reserves Giumalău, Călimani and Voievodeasa, in the eastern Carpathians (Fig. 1). The third, Hylastes linearis Erichson, 1836, was caught at Zamostea, in the northern part of the Molda- vian Plateau.

Collecting methods. Beetles of T. laeve and $X$. germanus were collected using interception traps made from polyethylene, while $H$. linearis was captured in a flight intercept trap made from black plastic and baited with alpha-pinene and ethanol. The trapping periods, numbers of traps, their placement and insect collection interval are presented in Table 2.

Species identification. The identification of scolytid species was done using the key published by Pfeffer (1995) and the nomenclature for this group of insects is that used in the Catalogue of Palaearctic Coleoptera (Knížek 2011). 
Table 2 Details concerning the collection of insects

\begin{tabular}{llllll}
\hline Location & Year & Trapping periods & $\begin{array}{l}\text { Number } \\
\text { of traps }\end{array}$ & $\begin{array}{l}\text { Trap placement } \\
\text { (rows x traps) }\end{array}$ & $\begin{array}{l}\text { Collection } \\
\text { interval }\end{array}$ \\
\hline \multirow{3}{*}{ Giumalău } & 2007 & 18 May-20 Sept. & 20 & $(2 \times 5)+(2 \times 5)$ & 2 weeks \\
& 2008 & 19 May-30 Sept. & 20 & $(2 \times 5)+(2 \times 5)$ & 2 weeks \\
& 2009 & 14 May-21 Sept. & 32 & $(2 \times 5)+(2 \times 5)+(2 \times 6)$ & 2 weeks \\
\hline Călimani & 2010 & 26 May-21 Sept & 20 & $4 \times 5$ & 2 weeks \\
\hline \multirow{2}{*}{ Voievodeasa } & 2011 & 10 May-26 Sept. & 20 & $4 \times 5$ & 2 weeks \\
\hline Zamostea & 2012 & 3 May-20 Sept. & 20 & $4 \times 5$ & 2 weeks \\
\hline
\end{tabular}

\section{Results and discussion}

\section{Trypodendron laeve}

A total of 35 specimens of Trypodendron laeve (Fig. 2) were caught during this study, 24 in Giumalău and 11 in Călimani (Table 3). In Giumalău, there were no captures in 2007 and only 7 and 17 in 2008 and 2009, respectively. Captures occurred all through the season.

Morphologically this species is most closely allied to T. lineatum (Olivier 1795), except that the colour of elytra is more uniformly brown without evident darker and lighter longitudinal strips. It is totally devoid of microscopic tubercles on the elytral declivity and has darker brown legs, with the femur of all three pairs nearly black.

This is the first report of this species in Romania. It was found only locally at high altitudes (above $1230 \mathrm{~m}$ ), in the forest reserves Giumalău and Călimani. Other locations at different altitudes were studied also, sites at which many specimens of $T$. lineatum were collected, but none of $T$. laeve (unpublished data). This would seem to strengthen the hypothesis that T. laeve is a boreo-montane species (Bussler \& Schmidt 2008a, b), although it has also been found at lower altitudes in central Europe (Krehan \& Holzschuh 1999, Bussler \& Schmidt 2008b, Lukášová et al. 2012).

The discovery of this species in old forests at high altitudes, very far from the wood trade corridors, but not in forests at low alti90

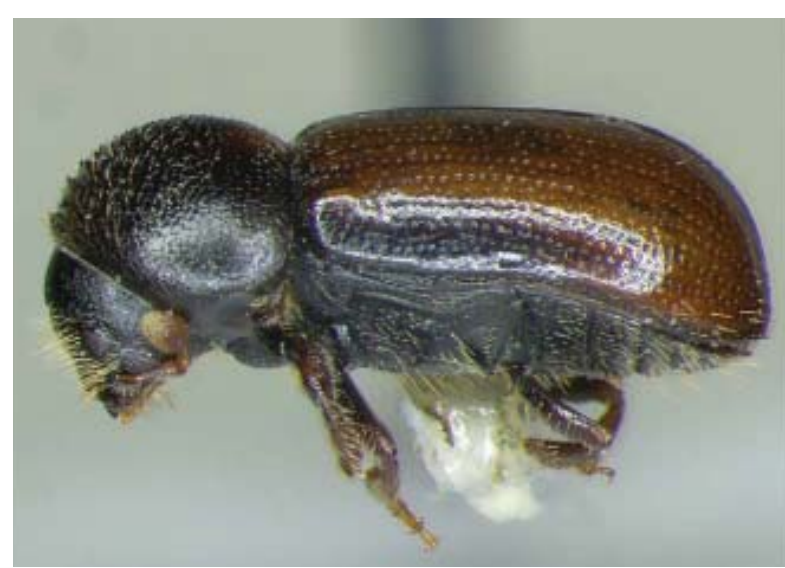

Figure 2 Lateral view of Trypodendron laeve

Table 3 Trypodendron laeve captures

\begin{tabular}{|c|c|c|c|}
\hline Location & Year & $\begin{array}{l}\text { Collection } \\
\text { date }\end{array}$ & $\begin{array}{l}\text { Number } \\
\text { of beetles } \\
\text { captured }\end{array}$ \\
\hline \multirow{10}{*}{ Giumalău } & \multirow{6}{*}{2008} & 3 June & 1 \\
\hline & & 17 July & 2 \\
\hline & & 29 July & 1 \\
\hline & & 13 August & 2 \\
\hline & & 26 August & 1 \\
\hline & & TOTAL & 7 \\
\hline & \multirow{4}{*}{2009} & 10 August & 12 \\
\hline & & 24 August & 3 \\
\hline & & 7 September & 2 \\
\hline & & TOTAL & 17 \\
\hline \multirow{4}{*}{ Călimani } & \multirow{4}{*}{2010} & 29 July & 1 \\
\hline & & 12 August & 2 \\
\hline & & 25 August & 8 \\
\hline & & TOTAL & 11 \\
\hline
\end{tabular}

tudes where greater management activities and wood transport operations occur, might be an argument supporting the theory that $T$. laeve is 
in fact a native species and not alien to Europe (Kirkendall \& Faccoli 2010).

In this study $T$. laeve was probably only caught at very low numbers in each year and at each location because its abundance in central Europe is low generally (Lukášová et al. 2012). The captures were scattered throughout the season, from the end of May to AugustSeptember, without any definite distribution pattern. It seems that the beetles caught were almost exclusively young, probably searching for places to overwinter (Bussler \& Schmidt 2008a, b), and not the insects that had developed in the previous year. The main flight, which is very short and occurs earlier in the year, when snow may still be on the ground (Kvamme 1986, Krehan \& Holzschuh 1999, Martikainen 2000, Öhrn et al. 2011), probably took place before the trapping period. In order to obtain a clear picture of Trypodendron species distribution and abundance in Romania, a study using pheromone traps such as those implemented in the Czech Republic and Poland (Lukášová et al. 2012), and covering the whole flight period, would be desirable.

\section{Xylosandrus germanus}

Xylosandrus germanus (Fig. 3) were captured in high numbers in Voievodeasa Forest Reserve in both 2011 and 2012, totalling 71 and 97 females, respectively. The flight peak was in the middle of June (Fig. 4).

All of the traps, with the exception of two in 2011, caught this species, resulting in a mean number of 3.6 (1S.D.: 2.7) and 4.9 (1S.D.: 3.4) individuals per trap in 2011 and 2012, respectively. There was no obvious influence of the altitudinal gradient on the captures. In 2012, the most individuals (17) were found in a trap situated at about $900 \mathrm{~m}$ altitude, in a place with more than 2000 hours insolation year-1.

With the exception of the body size and certain generic characteristics, Xylosandrus germanus is in general terms morphologically similar to the indigenous Anisandrus dispar

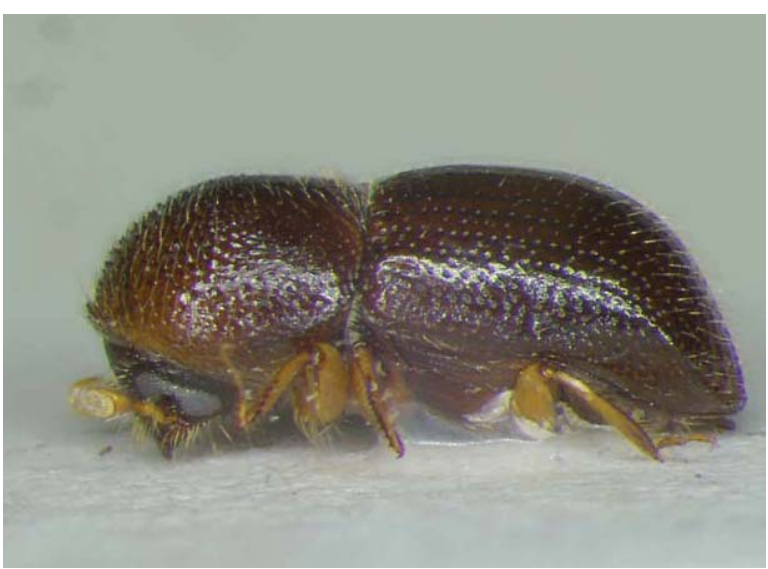

Figure 3 Lateral view of a female of Xylosandrus germanus
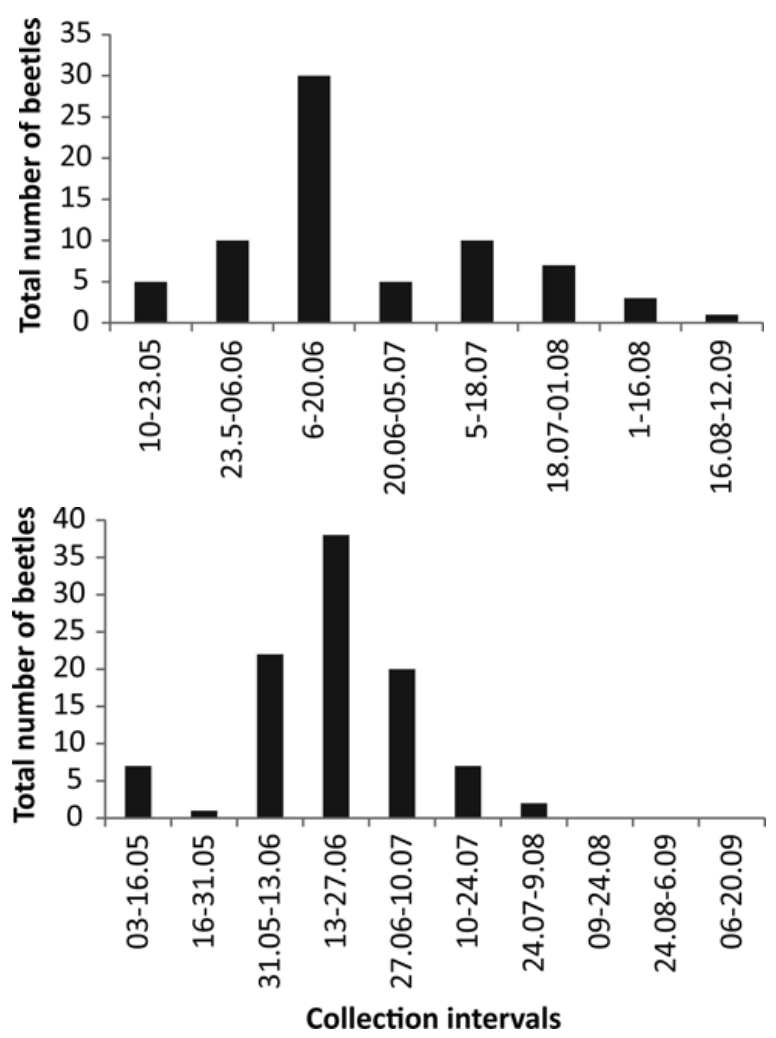

Figure 4Dynamics of Xylosandrus germanus captures in Voievodeasa Forest in 2011 (top) and 2012 (bottom)

(Fabricius 1792). X. germanus, however, is an alien invasive species in Europe (DAISIE 2009, Kirkendall \& Faccoli 2010). Its native area is eastern Asia and the insect was accidentally introduced to Europe after the Second World War (Groschke 1952). In the years 
since it has spread and become established in many countries (Knížek 2011). Everywhere the species has established, it has permanent populations only at relatively low elevations (Holzschuh 1995, Bruge 1995, Henin \& Versteirt 2004, Bense 2006), with the highest population reported to date at 578-600 m (Bussler et al. 2010, Blaschke \& Bussler 2012). In Voievodeasa Forest a permanent population was discovered at an altitude of 760-900 m, on a slope with a south-easterly aspect.

In a similar study of saproxylic beetles conducted in a mixed sessile oak and beech forest at Runcu-Groşi $\left(46^{\circ} 11^{\prime} \mathrm{N}, 2^{\circ} 07^{\prime} \mathrm{E}\right.$, at 455 $572 \mathrm{~m}$ ) in south-western Romania in 2008, no $X$. germanus specimens were found; this was the case although Runcu-Groși is not far from the border with Hungary, where the species has been present since 2005 (Lakatos \& Kajimura 2007). It would seem that this alien species is still only represented by small local populations in both countries and does not have a generalised distribution like the indigenous Anisandrus dispar. However, the species continues to spread and may yet colonise further areas in Romania, and in Europe.

The beetle's flight dynamics in Voievodeasa Forest were similar to the observations made by Graf \& Manser (2000) and Bussler \& Müller (2004), beginning early in May, with a maximum in June-July, and corresponding to one generation per year. The low catch number in May 2012 was due to the rainy weather conditions that prevailed throughout almost the whole month.

There is no information as to how this species arrived in the northern part of Romania, but the high number of captures of $X$. germanus may indicate a long-term development of the population in this area or a high degree of habitat favourability for this species. As it has a very large range of host plants, including both deciduous and coniferous trees, its spread to a large part of Romania's forests can be expected, especially in broadleaf forests growing at altitudes up to $700-900 \mathrm{~m}$, where the stress caused by a warming climate is also more severe.

\section{Hylastes linearis}

One specimen of Hylastes linearis (Fig. 5) was found on 3 May 2010 at Zamostea, Suceava county.

Hylastes linearis differs from all other known central European Hylastes species in its body proportions, mainly the pronotum. Possessing a very distinct, slim body form, the species' body size ranges between 3.0-4.5 $\mathrm{mm}$ (medium size species) and it is dark brown in colour. It has a rostrum with a longitudinal fine keel, the pronotum markedly longer than it is wide with a ratio of 1.2-1.35 (0.9-1.2 in other species), with the widest part in the anterior half (in the posterior or near to the base in other species). The pronotal punctures are longitudinal (round in other species) and the elytra are twice as long as they are wide (the highest ratio on average in comparison with other species).

This European-Mediterranean species (Gatti 2011) is widely distributed in Europe, but is not present in the Scandinavian or Baltic countries (Knížek 2011). Larval development takes place in the dead roots and stumps of several Pinus species (Pfeffer 1995), including P. sylvestris and $P$. nigra var. austriaca, which are preferred hosts (Gatti 2011). Its preference for a milder climate and the scarcity of hosts might explain why the species was not found in Romania previously. The species appears

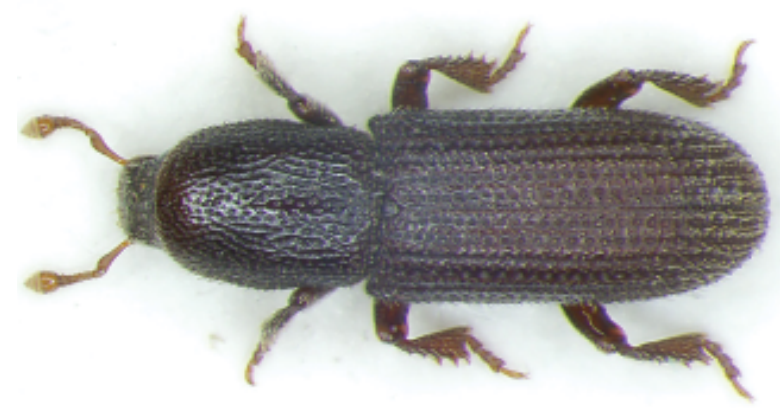

Figure 5 Dorsal view of Hylastes linearis 
to be quite rare overall, as stated by Eichhoff (1881).

\section{Acknowledgements}

The research presented was conducted within the following projects: CEEX-C719/2006 NATFORMAN, PN 09460203/2009, PNIIPT-PCCA-2011-3.2-1574 / Contract number $119 / 2012$, all funded by the Romanian Ministry of National Education for NO, VO, MLD and IAB. For MK the research was partly supported from provided institutional support for long-term conceptual development of research organization MA CR - Decision No. RO0114 (reference number 8653/2014- MZE-17011). We thank the two anonymous reviewers, who analysed a previous version of the manuscript, for their valuable comments, as well as David Butler Manning (Dresden University of Technology) for English revision.

\section{References}

Bense U., 2006. Zur Totholzkäferfauna von laubholzreichen Sturmwurfflächen in Baden-Württemberg [To deadwood beetle fauna of deciduous trees rich windthrow areas in Baden-Württemberg]. Waldschutzgebiete in Baden-Württemberg 11: 75-147.

Bielz E.A., 1851. Systematisches Verzeichnis der Käfer Siebenbürgens [Systematic list of the beetles of Transylvania]. Verhandlungen und Mitteilungen des Siebenbürgischen Vereins für Naturwissenschaften zu Hermannstadt 2: 18-40.

Bielz E.A., 1887. Die Erforschung der Käferfauna Siebenbürgens bis zum Schlüsse des Jahres 1886 [The study of the beetle fauna of Transylvania to the close of the year 1886]. Verhandlungen und Mitteilungen des Siebenbürgischen Vereins für Naturwissenschaften zu Hermannstadt 37: 27-105.

Blaschke M., Bussler H., 2012. Borkenkäfer und baumschädigende Holzpilze in einem Höhengradienten des Bayerischen Waldes [Bark beetles and tree-damaging wood fungi in an altitudinal gradient of the Bavarian Forest]. Forstschutz Aktuell 54: 10-15.

Bruge H., 1995. Xylosandrus germanus (Blandford, 1894) [Belg. Sp. nov.] (Coleoptera, Scolytidae). Bulletin et Annales de la Societe Royale Belge d'Entomologie 131: 249-264.

Bucşa C., Curtean A., 1995. Studiul cenologic al scoliti- delor (Coleoptera, Scolytidae) din Pădurea Dumbrava Sibiului [Cenologic study of scolitids (Coleoptera, Scolytidae) in the Dumbrava Sibiului Forest]. Acta Oecologica. Studii şi comunicări de ecologie şi protecția mediului 2(1-2): 25-49.

Bussler H., Blaschke M., Walentowski H., 2010. Bemerkenswerte xylobionte Käferarten in Naturwaldreservaten des Bayerischen Waldes (Coleoptera) [Notable saproxylic beetle species in natural forest reserves of the Bavarian Forest (Coleoptera)]. Entomologische Zeitschrift 120(6): 263-268.

Bussler H., Müller J., 2004. Borkenkäferzönosen in wärmegetönten Eichenmischwäldern Nordbayerns [Bark beetle cenoses in warm mixed oak forests in northern Bavaria]. Forst und Holz 59(4): 175-178.

Bussler H., Schmidt O., 2008a. Trypodendron laeve Eggers, 1939 - Ein wenig bekannter Nutzholzborkenkäfer [Trypodendron laeve Eggers, 1939 - A little known ambrosia beetle]. Forstschutz Aktuell 45: 11-13.

Bussler H., Schmidt O., 2008b. Remarks on the taxonomy, distribution and ecology of Trypodendron laeve Eggers, 1939 (Coleoptera: Scolytidae). Nachrichtenblatt der Bayerischen Entomologen 57(3/4): 62-65.

DAISIE, 2009. Handbook of alien species in Europe. Springer, Dordrecht, $400 \mathrm{p}$.

Eggers H., 1911. Beiträge zur Kenntnis der Borkenkäfer. Entomologische Blätter 7(4): 73-76, 7(5-6): 119-123.

Eichhoff W., 1881. Die Europäischen Borkenkäfer [The European bark beetles]. Verlag von Julius Springer, Berlin, $315 \mathrm{p}$.

Faccoli M., Frigimelica G., Mori N., Toffolo E.P., Vettorazzo M., Simonato M., 2009. First record of Ambrosiodmus (Hopkins, 1915) (Coleoptera: Curculionidae, Scolytinae) in Europe. Zootaxa 2303: 57-60. DOI: 10.11646/zootaxa.3722.1.8.

Faccoli M., Sidoti A., 2013. Description of Phloeosinus laricionis sp. n. (Coleoptera: Curculionidae, Scolytinae), a new bark beetle species from southern Europe. Zootaxa 3722(1): 92-100.

Fleck E., 1904-1905: Die Coleopteren Rumäniens [The Coleoptera of Romania]. Buletinul Societății de Sciințe din Bucuresci - Romania 13(3-4): 308-346, 13(5-6): 402-465, 14(1-2): 158-203, 14(4): 403-450, 14(5): 491570, 14(6): 680-735.

Gatti E., 2011. I Coleotteri Scolitidi e Platipodidi della Sardegna (Coleoptera: Scolytidae, Platypodidae) [The scolytids and platypodids of Sardinia (Coleoptera: Scolytidae, Platypodidae)]. In: Nardi, G., Whitmore, D., Bardiani, M., Birtele, D., Mason, F., Spada, L., Cerretti, P. (eds), Biodiversity of Marganai and Montimannu (Sardinia). Research in the framework of the ICP Forests network. Conservazione Habitat Invertebrati 5: 609-639. Cierre Edizioni, Sommacampagna, Verona. $896 \mathrm{p}$.

Graf E., Manser P., 2000. Beitrag zum eingeschleppten Schwarzen Nutzholzborkenkäfer Xylosandrus germanus. Biologie und Schadenpotential an im Wald gelagertem Rundholz im Vergleich zu Xyloterus lineatus 
und Hylecoetus dermestoides [The imported Japanese scolytid beetle Xylosandrus germanus: Biology and damage potential for stored round timber compared to Xyloterus lineatus and Hylecoetus dermestoides]. Schweizerische Zeitschrift für Forstwesen 151: 271281. DOI: $10.3188 /$ szf.2000.0271.

Groschke F., 1952. Der „Schwarze Nutzholzborkenkäfer“ Xylosandrus germanus Blandf., ein neuer Schädling in Deutschland [The „Black ambrosia“ Xylosandrus germanus Blandf., a new pest in Germany]. Zeitschrift für Angewandte Entomologie 34: 297-302. DOI: 10.1111/ j.1439-0418.1953.tb00698.x.

Henin J.-M., Versteirt V., 2004. Abundance and distribution of Xylosandrus germanus (Blandford 1894) (Coleoptera, Scolytidae) in Belgium: new observations and an attempt to outline its range. Journal of Pest Science 77: 57-63. DOI: 10.1007/s10340-003-0030-5.

Holzschuh C., 1995. Forstschädlinge, die in den letzten fünfzig Jahren in Österreich eingewandert sind oder eingeschleppt wurden [Forest pests that have immigrated or were introduced over the last fifty years in Austria]. Stapfia 37: 129-141.

Hulcr J., Rountree N.R., Diamond S. E., Stelinski L.L., Fierer N., Dunn R. R., 2012. Mycangia of ambrosia beetles host communities of bacteria. Microbial Ecology 64: 784-793. DOI: 10.1007/s00248-012-0055-5.

Kirisits T., 2004. Fungal associates of European bark beetles with special emphasis on the ophiostomatoid fungi. In: Lieutier F., Day K., Battisti A., Grégoire J. C., Evans, H. (eds.), Bark and wood boring insects in living trees in Europe, a synthesis. Kluwer, Academic Publishers, Dordrecht. pp. 181-236. DOI: 10.1007/9781-4020-2241-8_10.

Kirkendall L.R., Faccoli M., 2010. Bark beetles and pinhole borers (Curculionidae, Scolytinae, Platypodinae) alien to Europe. ZooKeys 56: 227-251.

Kirkendall L.R., Dal Cortivo M., Gatti E., 2008. First record of the ambrosia beetle, Monarthrum mali (Curculionidae, Scolytinae) in Europe. Journal of Pest Science 81: 175-178. DOI: 10.1007/s10340-008-0196-y.

Knížek M., 2011. Scolytinae. In: Löbl I., Smetana A. (eds.), Catalogue of Palearctic Coleoptera, Vol. 7: 8687, 204-251. Apollo Books, Stenstrup, 373 p.

Knížek M., Beaver R., 2007. Taxonomy and systematics of bark and ambrosia beetles. In: Lieutier F., Day K.R., Battisti A., Grégoire J.-C., Evans H.F. (eds.), Bark and wood boring insects in living trees in Europe, a synthesis. Kluwer Academic Publishers, Dordrecht. pp. 41-54.

Kocs I., 2010. A Magyar Természettudományi Múzeum Bogárgyűjteményében Található, Székelyföldön gyüjtött ormányosalkatú bogarak fajlistája (Coleoptera: Curculionoidea) [Species list of Curculionoidea collected in Székelyföld in the collection of the Hungarian Natural History Museum]. Acta Siculica 2010: 105-121.

Krehan H., Holzschuh C., 1999. Trypodendron laeve - Vorkommen in Österreich [Trypodendron laeve - occurrence in Austria]. Forstschutz Aktuell 23-24: 6-8.
Kvamme T., 1986. Trypodendron piceum Strand (Col., Scolytidae): Flight period and response to synthetic pheromones. Fauna Norvegica Series B 33: 65-70.

Lakatos F., Kajimura H., 2007. Occurrence of the introduced Xylosandrus germanus (Blandford, 1894) in Hungary - a genetic evidence (Coleoptera: Scolytidae). Folia Entomologica Hungarica 68: 97-104.

Lukášová K., Knížek M., Holuša J., Čejka M., Kacprzyk M., 2012. Is the bark beetle Trypodendron laeve (Coleoptera: Curculionidae: Scolytinae) an alien pest in the Czech Republic and Poland? Polish Journal of Ecology 60(4): 789-795.

Marcu O., 1926. Die in der Bukowina als schädlich und minderschädlich nachgewiesenen Borkenkäfer (Scolytidae) [The bark beetles (Scolytidae) proven to be harmful and less harmful in Bukovina]. Verhandlungen und Mitteilungen des Siebenbürgischen Vereins für Naturwissenschaften zu Hermannstadt 75-76: 57-67.

Marcu O., 1934. Die Ipidenfauna von Rumänien [The Ipidenfauna of Romania]. Bulletin de la Section Scientifique, Académie Roumaine 16(1-3): 54-61.

Marcu O., 1941. Nachtrag zur Kenntnis der Verbreitung und Biologie der Ipiden (Coleoptera) in Rumänien [Addendum to the knowledge of the distribution and biology of scolytids (Coleoptera) in Romania]. Annales Scientifiques de l'Université de Jassy 27(2): 399-403.

Marcu O., 1957. Pityophthorus lichtensteini Ratzbg., un nou bostrichid pentru fauna Coleopterelor din R. P. R. [Pityophthorus lichtensteini Ratzbg., a new bostrichid of beetle fauna of Romania]. Studii şi Cercetări de Biologie 8(12): 213-215.

Martikainen P., 2000. Flight period and ecology of Trypodendron proximum (Niijima) (Col., Scolytidae) in Finland. Journal of Applied Entomology 124: 57-62. DOI: 10.1046/j.1439-0418.2000.00446.x.

Müller J., Bußler H., Goßner M., Rettelbach T., Duelli P., 2008. The European spruce bark beetle Ips typographus in a national park: from pest to keystone species. Biodiversity and Conservation 17: 2979-3001. DOI: 10.1007/s10531-008-9409-1.

Negru Ş., 1955. Xyleborus pfeili Ratz. (Coleop. Ipidae) un element nou pentru fauna R.P.R. [Xyleborus pfeili Ratz. (Coleop. Ipidae) a new element in the Romanian fauna]. Revista Pădurilor 70(1): 45.

Negru Ş., 1960. Ernopocerus caucasicus (Lind.), element nou pentru fauna R. P. R. [Ernopocerus caucasicus (Lind.), a new element in the Romanian fauna]. Comunicările Academiei R.P.R. 10(1): 33-37.

Negru Ş., 1965. Über drei für die rumänische Fauna neue Borkenkäfernarten [About three for the Romanian fauna new species of bark beetles]. Entomologische Blätter 61(2): 113-120.

Negru Ş., 1967. Coleoptera-Scolytidae du delta du Danube [Coleoptera-Scolytidae of Danube Delta]. Travaux du Muséum d'Histoire Naturelle "Grigore Antipa", Bucharest 7: 313-316.

Negru Ş., 1968. Les Scolytoides (Coleoptera, Scolytoidea) de la collection scientifique du Musee "Grigore Antipa" 
[The Scolytoids (Coleoptera, Scolytoidea) in the scientific collection of the Museum «Grigore Antipa»]. Travaux du Muséum d'Histoire Naturelle "Grigore Antipa" 9: 453-459.

Negru Ş., 1971. Scolitidi (Coleoptera, Scolytidae) della zona del futuro bacino d'accumulazione "Porțile de Fier" [Bark beetles (Coleoptera, Scolytidae) in the area of the future accumulation reservoir «Portile de Fier»]. Travaux de Muséum d'Histoire Naturelle "Grigore Antipa" 11:175-189.

Negru Ş., Ceianu I., 1957. Contribuțiune la recunoaşterea lui Ips duplicatus Sahib. şi a vătămării produse [Contribution to the recognition of Ips duplicatus Sahib. and of its damage]. Analele Universității “C.I. Parhon”, Seria Ştiințele Naturii 13: 157-161.

Negru Ş., Pîrvescu D., 1955. Ips sexdentatus Boern. un element rar pentru fauna R.P.R. [Ips sexdentatus Boern. a rare element in the Romanian fauna]. Revista Pădurilor 70(9): 426-427.

Öhrn P., Lindelöw Å., Långström B., 2011. Flight activity of the ambrosia beetles Trypodendron laeve and Trypodendron lineatum in relation to temperature in Southern Sweden. In: Delb H., Pontuali D. (eds.), Biotic risks and climate change in forests. Berichte Freiburger Forstliche Forschung, FVA, Freiburg, pp. 86-90.

Pascovici V.D., 1962. Contribuții la problema bioecologiei gândacilor de scoarță (Scolytidae) în legătură cu uscarea ulmului [Contributions to the problem of bark beetle (Scolytidae) bioecology in relation to elm's dieback]. Revista Pădurilor 77(5): 301-304.

Persson Y., Ihrmark K., Stenlid J., 2011. Do bark beetles facilitate the establishment of rot fungi in Norway spruce? Fungal Ecology 4(4): 262-269. DOI: 10.1016/ j.funeco.2011.01.005.

Petri K., 1912. Siebenbürgens Käferfauna auf Grund ihrer Erforschung bis zum Jahre 1911 [Beetle fauna of Transylvania on the basis of its research until 1911]. Drotleff, Hermannstadt. 376 p.
Pfeffer A., 1995. Central und Westpaläarktische Borkenund Kernkäfer (Coleoptera: Scolytidae, Platypodidae) [Central and Western Palearctic bark beetles and pinhole borers (Coleoptera: Scolytidae, Platypodidae)]. Pro Entomologia, Naturhistorisches Museum, Basel. $310 \mathrm{p}$.

Postner M., 1974. Scolytidae (= Ipidae), Borkenkäfer [Scolytidae (= Ipidae), bark beetles]. In: Schwenke W. (ed.), Die Forstschädlinge Europas. 2. Band. Paul Parey, Hamburg und Berlin, pp. 334-482.

Six D.L., 2013. The bark beetle holobiont: Why microbes matter. Journal of Chemical Ecology 39: 989-1002. DOI: $10.1007 / \mathrm{s} 10886-013-0318-8$.

Stokland J.N., 2012. The saproxylic food web. In: Stokland J.N., Siitonen J., Jonsson B.G., (eds.), Biodiversity in dead wood: Cambridge University Press, Cambridge, pp. 29-57. DOI: 10.1017/CBO9781139025843.004.

Stokland J.N., Siitonen J., 2012. Mortality factors and decay succession. In: Stokland J.N., Siitonen J., Jonsson B.G., Biodiversity in dead wood. Cambridge University Press, Cambridge, pp. 110-149. DOI: 10.1017/ CBO9781139025843.007.

Tudor C., 1969. Chalcidoide parazite ale coleopterelor (Scolitide şi Cerambicide) [Chalcidoidea parasitic on Coleoptera (Scolytidae and Cerambycidae)]. Studii şi Cercetări de Biologie, Seria Zoologie 21(1): 29-34.

Vasiliu M., Zaharia D., Ignat C., 1978. Catalogul scolitidelor din colecția „Ştefan Negru” a Muzeului Județean Suceava (Coleoptera, Scloytoidea) [The catalogue of scolytids (Coleoptera, Scloytoidea) from ,Stefan Negru" Collection of Suceava County Museum]. Studii şi Comunicări, Ştiințele Naturii, Muzeul Județean Suceava, 1978: 37-58.

Wood S.L., 1982. The bark and ambrosia beetles of North and Central America (Coleoptera: Scolytidae), a taxonomic monograph. Great Basin Naturalist Memoirs (6). Brigham Young University, Provo, Utah. 1359 p. 